\title{
Catecismo Castellano - Cakchikel
}

\author{
LUIS RESINES \\ Estudio Teológico Agustiniano de Valladolid
}

Resumen: En el presente artículo se ofrece al lector un desconocido catecismo bilingüe, castellano y cachiquel, lengua propia de Guatemala. En realidad se trata de un impreso que contiene un catecismo, junto con un ritual para el viático y el matrimonio. El impreso hay que situarlo en el siglo XVIII, escrito por un autor desconocido, quizá franciscano. El catecismo tiene un notable desorden, y además está incompleto, pues prácticamente no aborda los mandamientos; quizá este cometido se reserva para el confessionario que le complementa, también bilingüe. A pesar de sus fallos, puede haber constituido un modelo para llevar a cabo la evangelización en Guatemala, siguiendo la norma ya iniciada dos siglos antes por el obispo Francisco Marroquín en el siglo XVI.

Palabras clave: Catecismo, Cakchikel (Cachiquel), Confessionario, Ritual, Marroquín.

Abstract: This article shows a unknown bilingual catechism, Spanish and Cakchiquel, language of Guatemala, dated perhaps at XVIII century. Two little books integrate it: a catechism, and a ritual for viaticum and marriage. The catechism have no author, may be a Franciscan friar. It have very disorder in its themes; and also is not complete, by absence of commandments. This is a target for the complementary confessional book. It have a precedent in XVI century, in the catechism of bishop Francisco Marroquin.

Key Words: Catechism, Cakchiquel (Cachiquel), Confessional book, Ritual, Marroquin. 
Ha llegado a mis manos una magnífica copia de un catecismo, como una generosa donación de la comunidad franciscana de Alto del Rollo, en Salamanca. El catecismo reviste no pocas dificultades a la hora de situarlo adecuadamente, como cabría desear.

El ejemplar del que ha sido copiado está integrado en los fondos del Archivo franciscano de Santiago de Compostela, y la fotocopia permite examinarlo con toda clase de detalles, salvo en aquellas partes o anotaciones que se han ido perdiendo con el paso del tiempo.

Es una gustosa tarea proceder a su examen, a fin de darlo a conocer, y, en la medida de lo posible, llegar a valorarlo.

\section{DESCRIPCIÓN}

Se trata de un folleto de 20 x 15,5 cm., constituido por 16 hojas, cosidas para darle unidad dispuestas en tres cuadernillos. El primero carece de signatura propia, que tendría que ser $\mathrm{A}^{4}$, el segundo tiene la signatura $\mathrm{B}^{4}$, y el tercero corresponde a $\mathrm{C}^{8}$. Los tres constituyen todo el folleto, que no tiene desgarros ni pérdidas de papel, que supongan un deterioro en el texto.

Envuelve al conjunto una hoja doble que aparece al principio y al final, como hoja de respeto o también como protección. Habrá que volver sobre ella. El conjunto ha sufrido en algún momento de su historia la acometida del agua, que lo ha empapado desde la parte superior a la inferior y ha dejado en todas sus páginas una enorme mancha de humedad que ocupa algo más de la mitad de cada página; no obstante, es posible leer sin dificultad su contenido.

Las hojas han sufrido por el uso reiterado, y están fatigadas en los márgenes así como en la esquina superior, pero tampoco eso afecta al texto impreso.

Además de la hoja de papel destinada a la protección del escrito, a la que me he referido, todo ello aparece encuadernado con una cubierta de cuero repujado, con una labor exquisita que muestra un marco muy finamente detallado y elaborado, un gran círculo central, radiado, y cuatro secciones de círculo en los cuatro ángulos. Sin duda esta cubierta ha hecho posible que haya llegado hasta nuestros días en plena integridad, a pesar de las deficiencias señaladas. 
El texto impreso carece de nombre de autor, así como tampoco tiene una portada como es usual, ni pie de imprenta o colofón que permitan hacer alguna aproximación que desvele su origen, o a quién se debe su texto.

Este en realidad está integrado por dos escritos perfectamente diferenciados. El primero de ellos ocupa las 12 primeras hojas (24 páginas), y el segundo las 4 hojas restantes (8 páginas). Cada uno de ellos lleva un título propio, que los diferencia con nitidez. Por si esto no fuera suficiente razón para distinguirlos, el primero de los escritos, que constituye propiamente el catecismo, salvo en su título particular -que aparecerá más adelante-figura a dos columnas, constituidas por preguntas y respuestas, sin titulillos, ni ladillos. La columna de la izquierda es la que corresponde al texto cachiquel, en letra redonda; y la de la derecha contiene el texto en castellano, compuesto en cursiva. Ambas columnas llevan siempre sus respectivos reclamos.

Las dos columnas aparecen dispuestas en paralelo, pero, dado que el texto cachiquel es más amplio (supongo que por su propia construcción lingüística, o por la necesidad de emplear circunlocuciones), en la columna de la derecha, en castellano quedan espacios en blanco a fin de equilibrar el desarrollo de cada una y emparejar las enseñanzas en cada idioma. En los dos idiomas, todas las preguntas comienzan por «P.», y las respuestas por «R.»; desconozco el cachiquel y no sé cómo se dicen en ese idioma las voces «pregunta» $\mathrm{y}$ «respuesta», pero parece que eso no constituyó problema para señalarlas de esta forma con independencia de la respectiva lengua, a fin de identificar cuál era la interrogación y cuál su respuesta.

El segundo escrito está compuesto a renglón completo (no hay columnas), y dispone de una breve introducción en castellano (por tanto, en letra cursiva), más el texto que sigue en cachiquel (emplea la letra redonda). Como se trata de un ritual doble, para la comunión por viático y para el matrimonio, allí donde es preciso, es interrumpido por lo que en términos de imprenta se podría calificar como de titulillo, pero que en términos de ritual es una indicación ceremonial o rúbrica. Este doble ritual se completa con una oración final, en cachiquel.

Todo el texto carece de paginación, por lo cual, al hacer alguna referencia concreta, señalaré la página correspondiente entre corchetes. 


\section{FECHA Y AUTOR}

Como el impreso carece de toda pista tipográfica que indique procedencia, imprenta o lugar de impresión, que siempre sitúan una obra impresa, hay que moverse en el terreno de las conjeturas, lo que siempre resulta una cuestión espinosa.

Por el aspecto de la impresión, el tipo y el estilo de letra, así como por los adornos tipográficos que aparecerán en su momento, creo que hay que situar el impreso en el siglo XVIII; pero no pasa de una aproximación.

No hay fecha, ni nombre de autor, y el uso reiterado que delatan las pequeñas deficiencias indicadas muestra que no se trata de una copia que se tomara de la tirada, para enviarla a un Archivo a fin de que fuera conservada como testigo; lo que se percibe es que estamos ante un ejemplar que formó parte de esa tirada, fue ampliamente utilizado, y después, por alguna razón, fue encaminado al Archivo para ser conservado, sin que se sepa tampoco de cuántos ejemplares pudo constar la tirada, ni qué fue de ellos, o si éste es el único ejemplar sobreviviente.

No hay forma de averiguar dónde fue impreso, pero sí es posible suponer sin miedo a equivocación que procede de Guatemala, dado que la lengua cachiquel está vinculada a esta nación y es la empleada por su población indígena hasta nuestros días.

Poco más podría decirse, de no ser por la doble hoja en blanco que envuelve el texto impreso. En ese papel, en la hoja que al principio hace las veces de hoja de respeto, en el vuelto hay un texto manuscrito, valioso aunque solo en parte. Está escrito con tinta, y resulta bastante perdido, lo que deja sombras imposibles de despejar. Dicho texto manuscrito, en sus cuatro renglones, es:

«En lengua cachiquel.

... Guatemala (Antigua)

por Sebastián de ...

Año de 17...».

Las cuatro líneas conducen a unas afirmaciones, que desvelan muy poco más lo escaso que hasta ahora se puede asegurar con certeza:

$1^{\text {a }}$ línea. Confirma que el impreso es un texto en cachiquel. Además de poderlo asegurar por su uso en Guatemala, el comienzo del segundo 
escrito, el ritual ya apuntado, asegura que las oraciones que siguen están en «cakchikel».

$2^{a}$ línea. Falta al principio una palabra perdida, breve, que podría ser «hecho», «usado», «impreso» en Guatemala. La indicación de Antigua remite sin duda a la ciudad de Antigua, situada al oeste del país. Este indicio habla de su origen más concreto, y de la zona geográfica en particular, aunque esto no equivalga a situarlo como un impreso que se hubiera realizado en esa ciudad, ya que pudo ser llevado a cabo en un establecimiento tipográfico de cualquier otro lugar.

$3^{\text {a }}$ línea. La tercera línea apunta hacia el autor: Sebastián de..., pero la escritura está perdida, y solo permite vislumbrar que algún religioso franciscano de este nombre pudiera ser localizado en este lugar y en la fecha que sigue, para poder completar lo que la inscripción no desvela.

$4^{\text {a }}$ línea. La fecha está incompleta, o por mejor decir, señalada con puntos suspensivos: «17...». Es indicio claro de que la inscripción manuscrita es posterior, y que quien la escribió recordaba con aproximación la fecha en que Sebastián (...) ejerció su trabajo pastoral, pero no pudo precisarlo, y lo dejó en el aire.

La aproximación de 17... se refuerza con el estilo de un impreso, de factura propia del siglo XVIII, sin poder concretar más.

Por lo tanto, nos encontramos ante un impreso doble, un catecismo y un ritual sacramental (no completo) escrito (o solo utilizado) por Sebastián de (?), en Guatemala. Pudo ser impreso en Guatemala, en la ciudad de Antigua, en algún momento del siglo XVIII (17...), sin llegar a saber ni la fecha exacta, ni la imprenta en que se elaboró.

La razón de intuir que el autor fue franciscano no se puede deducir del nombre incompleto, ni siquiera del propio texto, que no ofrece pista alguna en este sentido. Hay que fundamentarla en el hecho de que los franciscanos misionaron en aquellas tierras, aunque no exclusivamente, y que el texto se encuentra conservado en el Archivo franciscano señalado; se puede concluir con un cierto grado de certeza.

Lo que el texto no dice es si se trata de un escrito que se elabora y a continuación se lleva a la imprenta porque entonces hubiera dónde im- 
primirlo o el responsable dispusiera de medios para realizar una tirada; o, por el contrario, que se tratara de un texto más antiguo, de origen incierto, que se venía utilizando en forma oral o manuscrita, y que fue impreso para ganar en limpieza, disponer de un texto fijo, no sometido a erratas de pronunciación o transcripción, a fin de darle estabilidad. Sin duda, esta suposición cabe dentro de lo posible, y, en ese caso, no hay forma de remontarse más allá para localizar su verdadero origen.

\section{LENGUA}

Como está indicado, el escrito consta de dos partes: un catecismo y un ritual incompleto. El primero es bilingüe en castellano y cachiquel; el segundo solamente en cachiquel, con algunas indicaciones -a modo de rúbricas- en castellano; también incluye algunas fórmulas en latín, como consecuencia de depender del ritual romano, entonces en latín para todos los lugares.

El idioma indígena empleado es la consecuencia de la adaptación a la cultura del pueblo indígena de Guatemala. El nombre del idioma aparece escrito en diferentes formas, según las fuentes que se consulten: Kaqchikel es la forma modernizada y actual que se emplea en nuestros días y con el que se enseña hoy; también aparece escrito como Cakchiquel o como Cachiquel. Y en el propio escrito figura con otra cuarta variante en la escritura: Cakchikel [p. 25].

Es uno de los idiomas del grupo lingüístico maya, hablado en la zona occidental de Guatemala, hacia la costa del Pacífico, que incluye la parte del territorio de México que hace frontera. Se ha conservado entre la población indígena, aunque hoy muchos hablen castellano y lo aprendan como muestra de la cultura propia del país. La gran presión gubernamental ejercida hace unos años sobre la población indígena mermó sus posibilidades, pero no ha eliminado su uso habitual.

Este ejemplar sigue los pasos trazados desde la primera evangelización del territorio, allá en el lejano siglo XVI, cuando Francisco Marroquín fue nombrado primer obispo de Guatemala ${ }^{1}$. Entonces, como consecuen-

${ }^{1}$ Francisco Marroquín era natural de Toranzo (Santander), pueblecito ubicado en el valle del mismo nombre, y se integró en el clero de Osma donde fue maestro de Filosofía 
cia de la necesidad de adaptación, publicó un catecismo, el primero de la nación, titulado Catecismo y Doctrina Cristiana en idioma Utlalteco, por el Illmo. Sr. D. Francisco Marroquín, Obispo de Guatemala, México, Juan Pablos, 1556. Se editó en México que era el único lugar en que por aquellas fechas se disponía de imprenta, hasta que Antonio Ricardo se instaló en Lima en 1583. Llama la atención que en el catecismo editado por Marroquín no aparezca en el título la referencia a la lengua cachiquel, sino al utlalteco, que es otra de las lenguas afines, también propia de Guatemala. No resultaba fácil hacer una edición, dado que, al alfabetizarla, los religiosos franciscanos y dominicos que realizaron tal labor transcribieron al-

y Teología. Como sacerdote integrado en la corte de Carlos V, Pedro de Alvarado le conoció e indujo a pasar a América. Cuando Alvarado se desplazó e instaló en Guatemala le nombró cura del pueblo recién fundado, y más adelante fue designado por el obispo de México como provisor y vicario general de aquella provincia. Preconizado obispo de Guatemala (18 de diciembre de 1834), se desplazó a México para ser ordenado. El 20 de octubre de 1537 llevó a cabo la erección de la diócesis guatemalteca. El sábado, 10 de septiembre de 1541, se produjo el célebre terremoto que asoló la naciente ciudad de Guatemala, que ya había sido desplazada a este nuevo emplazamiento, en el valle de Almolonga, consecuencia de otra erupción anterior y hubo de volcarse en ayuda de los supervivientes: murieron más de seiscientos indios y un número no preciso de españoles. La ciudad actual se conoce como La Antigua Guatemala, pues la capital actual fue objeto de nuevo emplazamiento.

En 1545 emprendió la visita a la provincia de Tuzulutlán, y, de regreso, se detuvo en la ciudad de Gracias a Dios, y posiblemente se entrevistó con Bartolomé de las Casas, a quien conocía de años atrás. En 1546 acudió de nuevo a México para asistir a la junta de prelados que había convocado el visitador Tello de Sandoval. En esa misma fecha, posiblemente durante su presencia en México, tuvo lugar en la imprenta de Juan Pablos la impresión de la Doctrina Christiana, que había elaborado en su diócesis, y con cuyos ejemplares regresó a su sede. No debió de ser del todo pacífica la reunión episcopal, por las acaloradas discusiones entre Marroquín y Las Casas sobre la aplicación de las Leyes Nuevas y el trato a los indios. De regreso de México pasó por Chiapas, donde puso la primera piedra de la iglesia de los dominicos. En su diócesis dio comienzo a las obras de la nueva catedral (tras el desplazamiento de la población de las faldas del volcán del Agua). Además de franciscanos y dominicos, consiguió que acudieran los mercedarios y trató sin conseguirlo que estuvieran presentes los jesuitas. Falleció el 9 de abril de 1563. Datos tomados de: Doctrina cristiana en lengua guatemalteca, ordenada por el Reverendísimo Señor Don Francisco Marroquín, primer obispo de Guatemala, y del consejo de su Majestad, con parecer de los intérpretes de las religiones del Señor Sancto Domingo y San Francisco Fray Juan de Torres y Fray Pedro de Betanzos, Santiago de Chile, Imp. Elzeviriana, 1905, III-XIII. También pueden consultarse: José Milla, Historia de la América Central (Guatemala), t. I, 1859; t. II, 1882; A. Gómez Carrillo, Estudio histórico sobre la América Central, San Salvador, 1884. 
gunos de los sonidos con signos gráficos que no figuran en el alfabeto latino, y hubo que componer nuevos tipos para reproducirlos.

Esto mismo aparece en una edición posterior que se hizo de este catecismo primero, pues de la primitiva edición no se conocen ejemplares sobrevivientes. Esta edición apareció con el largo título de: Doctrina cristiana en lengua guatemalteca, ordenada por el Reverendísimo Señor Don Francisco Marroquín, primer obispo de Guatemala, y del consejo de su Majestad, con parecer de los intérpretes de las religiones del Señor Sancto Domingo y San Francisco Fray Juan de Torres y Fray Pedro de Betanzos, Santiago de Chile, Imp. Elzeviriana, 1905. La edición de 1905 la llevó a cabo José Toribio Medina, y se anuncia en cubierta como «reimpresa a plana y renglón del único ejemplar conocido y precedida de una biografía de su autor» ${ }^{2}$.

El ejemplar ahora estudiado responde al mismo planteamiento, con una serie de signos propios, intercalados entre las letras del alfabeto latino, que hacen complicada, por no decir imposible, la mera transcripción del título, pues esos signos diferentes figuran en el mismo desde el comienzo del texto. Lo transcribiré de la forma más parecida posible, por si este estudio cae en manos de quien conozca el cachiquel.

\section{ESQUEMA DEL ESCRITO}

Descrito globalmente, todo el texto responde al siguiente esquema:

Parte primera: Catecismo [p. 1-24]

(Texto seguido a dos columnas, sin interrupciones).

Parte segunda: Ritual [p. 25-32]. Incluye:

- modo de dar el viático [p. 25]

- preguntas a los que se casan [p.31].

- para las arras [p. 32]

- alabado [p. 32]

${ }^{2}$ La referencia al único ejemplar conocido se concreta en un ejemplar de Guatemala, B. Antonio Velasco, 1724, que J. T. Medina conoció y reprodujo. 


\section{Parte Primera: Catecismo}

Es la parte más extensa de la obra. Responde a este título (con las dificultades de transcripción indicadas): Vae ri qutubal qhabal, salakiçabal pe richim Christianoil tzik Doctrina Christiana tucheex (En el título, las dos «q», más las dos «k», así como el fonema «tz» responden a signos diferentes de los del alfabeto latino).

El título está precedido con una cruz entre paréntesis, más cuatros adornos tipográficos (dos coronas en la parte superior y dos corazones en la inferior). El título propiamente dicho consta en tres líneas a plana completa, y a su término dan comienzo las columnas en los dos idiomas, como está indicado.

Se trata de un catecismo propiamente dicho. Está estructurado por preguntas y respuestas, que podría pensarse destinadas a ser aprendidas y repetidas de memoria; pero algunas, por su extensión notable (más aún en el cachiquel), es dudoso que pudieran retenerse de forma plena. Es un catecismo incompleto, como se verá a continuación, ya que no aborda todas las cuestiones importantes para un cristiano, por lo menos las fundamentales, y en algunas ocasiones incluye preguntas de importancia secundaria.

Es preciso leerlo con detenimiento para descubrir que parece tener como esquema vertebrador el credo, aunque no resulta demasiado seguro que sea así. Esto es muy evidente al comienzo, pero en un determinado momento parece abandonarlo para pasar a tratar cuestiones relativas a los sacramentos y el credo se difumina; retorna a él cuando se interesa por la cuestión de la comunión de los santos [p. 21], aunque a continuación vuelve a desviarse con preguntas sobre la cruz y sobre la Iglesia. La consecuencia de lo expuesto es clara: no se ve de forma sencilla por dónde discurren las preguntas, y en una minuciosa lectura se saca la conclusión de una cierta anarquía que salta de unas cuestiones a otras sin pauta alguna.

Para el análisis que sigue, avanzaré con arreglo al orden mismo en que aparecen las preguntas en el catecismo, lo que mostrará al final esa cierta anarquía en la organización de los temas. 


\section{Introducción [p. 1]}

Aparecen tres preguntas a modo de introducción que se interesan por la condición de cristiano y de bautizado para el que lea el catecismo. La primera pregunta es triple, lo que en alguna manera desconcierta: «P. En qué ley vives?, O qué vida tienes?, Eres por ventura christiano?».Esto da paso a la condición de bautizado, y pregunta por el motivo que lleva a las personas a bautizarse.

Como se ve, da por hecha una fase primera de pura evangelización a gentiles, y pasa (o al menos invita a ello con la intención) a que muchos o todos se bauticen. El motivo para acceder al bautismo lo expresa de la siguiente forma: «Porque (= para que) entre el alma en la ley de Christo y porque se le perdone el pecado original». Luego explicará qué es la ley de Cristo, o el estilo de vida cristiano, pero llama poderosamente la atención que desde el primer momento aparezca la cuestión del pecado original como si en esto consistiera el arranque de la evangelización. Esto es todo cuando enseña sobre el bautismo, del cual no vuelve a hablar cuando presenta los sacramentos [p. 9 y ss]. Pero no aporta explicación alguna sobre el pecado original, ya que lo da como algo conocido.

\section{Fe cristiana [p. 1-2]}

Las preguntas siguientes se centran en la fe que se acepta, y se confiesa. Son solo tres preguntas, pero resultan desconcertantes, especialmente la primera de ellas: «Si verdaderamente eres christiano, qué es lo que crees y confiesas? Un solo Dios confieso y creo de todo mi corazón». Resulta desconcertante porque con una pasmosa sencillez se deja a un lado el politeísmo y se da por sentado un convencimiento monoteísta, sin resistencias, sin dificultades, sin dudas. Cierto que si este catecismo data del siglo XVIII hay ya mucho andado, y son muchas las personas que nacen en un ambiente cristianizado desde mucho tiempo atrás, donde se ha olvidado el politeísmo. Pero no estoy seguro totalmente de que haya sucedido así de forma plena entre los indios de Guatemala del XVIII ${ }^{3}$.

${ }^{3}$ La razón de esta duda no es mera suposición. En un impreso diverso, que de alguna manera pudiera estimarse complementario del Catecismo, por su factura (más adelante me referiré a él), hay tres preguntas en torno al primer mandamiento que lo evidencian: «Has creydo en sueños en el Tecolote, en el Piiqhcô, o en otro Páxaro? / Sabes alguna brugería? / Has encendido Candelas, o quemado copal delante algún Palo, Piedra u otra cosa?». 
Es verdad que la respuesta -conforme al método de preguntas y respuestas- se pone en labios del catecúmeno para que al leerla, aprenderla y repetirla, la haga suya «de corazón», como señala; pero no es menos cierto que se puede leer y repetir una respuesta estereotipada y hacerlo sin convencimiento íntimo. De ahí que se pueda proclamar el monoteísmo aunque se sienta de otra manera y se mezcle con un politeísmo larvado.

La siguiente pregunta se centra en dónde está Dios, y la que le sigue pregunta por su obra creadora, el cielo y la tierra, lo visible y lo invisible, que conduce abiertamente a la confesión trinitaria: «Dios Padre, Dios Hijo y Dios Espíritu Santo, tres personas y un solo Dios; crió todo lo visible y lo invisible».

En tan solo tres preguntas queda superado el politeísmo, y se presenta el misterio de la Trinidad. No da la impresión de que el monoteísmo se presente en el catecismo como un simple sustituto del politeísmo, dado que propone rotundamente que se trata de un único Dios. Las preguntas que vienen a continuación, especialmente la que sigue sobre el Dios único («Quántos dioses hay?»), muestran que el tema no está definitivamente zanjado y necesita más explicación.

Pero no se puede pasar por alto que aparezca la palabra «Dios» tanto en el texto castellano (donde no extraña), como en la columna en cachiquel (donde sí que extraña). Se trata de una irresoluble cuestión que se había planteado tanto en Guatemala como en México. La palabra náhuatl «Teotl», como la palabra cachiquel «Cabovil» eran captadas por los indios a los que se evangelizaba, pues formaban parte de su universo mental; pero a la vez, inevitablemente, evocaba los dioses del paganismo. Por el contrario, el empleo de la palabra castellana «Dios» no llevaba adjunta esa evocación, pero era un concepto vacío, desconocido, referido a un dios nuevo, dotado de otros atributos. En Guatemala, los franciscanos se decantaron por el uso del término «Dios» (como aquí consta expresamente), en tanto que los dominicos fueron partidarios del empleo del término «Cabovil», con todos los riesgos mentales que aparejaba su uso. Los franciscanos se apoyaban en que el término «Dios» no era la traducción exacta del concepto «Cabovil», y que los resabios del paganismo podrían rebrotar. El catecismo primitivo de Marroquín, de tiempos de la primera evangelización (1566), incluye en el texto cachiquel la palabra «Dios» (en la versión conocida de 1905); no se puede olvidar que al obispo Marroquín le asesoraron el franciscano Juan de Torres y el dominico Pedro de Betanzos. 


\section{Dios único [p. 2]}

El tema de la unidad de Dios surge en la pregunta siguiente. Se formula una sola pregunta, además de la ya vista: «Quántos Dioses ay, según tu parecer? Verdaderamente un solo Dios reyna en mi corazón». La interrogación parece que deja la cuestión a la libre decisión de cada persona con el estribillo «según tu parecer».

De leerse solo la pregunta podría deducirse que es un asunto en que el parecer de cada uno resulta decisivo; pero unida a la respuesta correspondiente, la cosa cambia, con la preciosa expresión que apunta al convencimiento «reina en mi corazón». Dos preguntas -la anterior y ésta- para despejar las dudas sobre el Dios único. Posiblemente en el momento de la presentación primera de la religión cristiana, los indios guatemaltecos no lo tuvieran tan claro, ni habrían respondido con la misma sencillez y rapidez. Fue preciso despejar muchas dudas, responder a interrogantes profundos, desmontar convencimientos ancestrales, nada fáciles de cambiar, para que el monoteísmo cristiano reinara en los corazones de los nuevos convertidos. El presente catecismo muestra un estadio en que se da por superado el politeísmo por un nuevo estadio monoteísta, pacíficamente establecido.

\section{Dios trino [p. 2-3]}

Retorna la cuestión del Dios trino, que había sido presentado a propósito de la creación del mundo. Ahora son cinco las preguntas explicativas. Tres de ellas, intermedias, se refieren a los nombres de las tres divinas personas en particular, Padre, Hijo y Espíritu Santo, precedidos siempre del término «Dios». Las otras dos preguntas, primera y última, son casi una repetición: «Quántas son las personas de la Trinidad? Tres son las personas de la Trinidad; y en esta Trinidad de personas ay solamente un Dios»; «Son por ventura tres Dioses estas tres personas? De ninguna suerte son tres Dioses; tres son las personas, y estas tres personas son un solo Dios, poderoso Señor». Leídas ambas preguntas, una a continuación de otra, se percibe más nítida la repetición.

A ella habría que sumar que ya se había dicho en la cuestión de la creación que los cristianos aceptamos tres personas en un solo Dios. Parece suficiente la presentación catequética, sin entrar en otras cuestiones sobre si una persona es más y otra es menos, o su antigüedad, o su poder, o su procedencia. 
Más adelante saldrán dos afirmaciones necesarias para sustentar adecuadamente la fe cristiana en este punto concreto: ni la Virgen es diosa [p. 4], ni los santos son dioses [p. 20].

\section{Encarnación [p. 3-5]}

El tema que viene a continuación es el de la encarnación de Jesús, y su realidad humana. Se le dedican ocho preguntas. En la primera de ellas se presenta el hecho global de quién vino a la tierra «a tomar carne humana», «a tomar nuestra pobre naturaleza acá en la tierra»; y se desvela su nombre, presentado como «Jesu Christo». Esta forma de presentación y de escritura, en dos palabras separadas, es acomodada al estilo común del XVIII, al hablar de Jesucristo; no se utiliza de ordinario el nombre simple de Jesús. Se da por sentado como nombre propio lo que constituye en realidad un nombre y una misión, que los textos bíblicos diferencian cuando presentan a la persona (Jesús) como aquél en quien se centran las expectativas de la misión del Mesías prometido, y en quien tienen lugar las promesas de Dios ${ }^{4}$.

Al hablar de su encarnación es inevitable que aparezca la persona de María, de la que se afirma «siempre virgen», pero de la que se deja constancia en una pregunta expresa para esta cuestión, que no perdió su virginidad, y continuó virgen intacta antes, durante y después del parto. A renglón seguido aparece una pregunta no común: «Es por ventura Dios la Virgen María? No es Dios sino Madre de Christo, verdadero Hijo de Dios». Era preciso dejar clara la condición humana de María con una afirmación rotunda; a la vez resultaba preciso que los indios a los que se destinaba el catecismo identificaran y unieran en una misma y única persona las tres expresiones aparecidas: «Jesu Christo», «Christo», e «Hijo de Dios» ${ }^{5}$. Ésta es una labor que no aparece con nitidez en el catecismo, y

${ }^{4}$ Pablo enseñó en Tesalónica que «este mismo Jesús que yo os anuncio es el Mesías» (Hch. 17,3); por su parte, Apolo demostraba en la sinagoga de Éfeso que «Jesús es el Mesías» (Hch. 18, 28).

${ }^{5}$ Muchos españoles no estaban tan distantes de la mentalidad de los indios, pues en 1740 o 1741 Pedro Vives escribió en Valencia su catecismo, en el que, hablando de las personas divinas, señala estas preguntas: «P. ¿Quántas son las Personas de la Santíssima Trinidad? -R. Tres. / P. ¿Quáles son? -R. Padre, Hijo y Espíritu Santo. / P. ¿María Santissima no es Persona? -R. Sí Padre. / P. ¿Luego son quatro, Padre, Hijo, Espíritu Santo, y María San- 
que hay que suponer llevaran a cabo los catequistas, pues, de no hacerlo, subsistiría el equívoco de una persona con varios nombres o varias personas diferentes.

Este problema aparece claro en la pregunta siguiente, en sí misma totalmente válida, pero que podría provocar un cierto equívoco. La pregunta reitera lo que ya se había dicho a propósito de los nombres de las personas en el seno de la Trinidad santa, dice: «Nuestro Señor Jesu Christo es Dios? Es verdadero Dios, igual con el Padre y con el Espíritu Santo». En principio, nada que objetar desde la consideración teológica, irreprochable. Pero en la mente del indio que leía y trataba de aprender este catecismo aparecían dos expresiones que no se identificaban a primera vista: de Jesús se decía que era «Dios» y que era «Hijo de Dios». Dos preguntas seguidas; dos líneas inmediatas, y dos expresiones que requerían una explicación. Pero el texto no la da, al no ver su autor problema alguno en emplear términos comunes, si bien las frases podían tener resonancias diversas o confusas en quien las escuchaba sin aclaración alguna.

La pregunta última de este apartado cuestiona si Jesús (siempre «Jesu Christo») era realmente hombre. De nuevo, se precisaba aquí una explicación pausada, aunque la pregunta no la ofrece, dando por sentado que con afirmarlo era suficiente para acatar y aceptar el hondo misterio de quien es hombre y Dios.

\section{Redención [p. 5-6]}

Las preguntas que siguen ponen la enseñanza en la muerte de Jesús, focalizando en ella su actuación: vino a salvar a los hombres por medio de su muerte en la cruz. Resulta evidente que la voluntad de redactar un catecismo no muy extenso llevó a la decisión de omitir cualquier referencia a la actuación que desarrolló y que narran los evangelios: nada se dice de su actividad, de su predicación, de sus milagros, de sus discípulos, de las causas de su muerte,... Es un incómodo silencio que desfigura la persona de Jesús para dejar reducida su intervención a su muerte. El empleo del término «redención» parece que estuviera en contra del concepto de «salvación», que

tíssima? -R. No Padre, porque María Santíssima, aunque es Persona, es humana». (L. RESINES, Catecismo breve de Fray Pedro Vives (Edición crítica), Valencia, Ayuntamiento de Valencia, 2002, 135). 
lleva aparejado el anuncio del Reino de Dios, la proclamación de la ley del amor, la fundación de la Iglesia, la llamada al discipulado...

La pregunta clave del catecismo en este punto se centra en dónde tuvo lugar la redención, cuya respuesta exacta es: «Verdaderamente fue hecha en la Cruz nuestra Redempción por el verdadero Hijo de Dios». Casi como un calco de cuál de las personas divinas se hizo hombre, otra pregunta pone su interés en cuál de las personas divinas murió en la cruz, y cuando pregunta por el motivo de su muerte, lo hizo «por pagar por nuestros pecados y abrir la puerta del cielo». Tal respuesta resulta sorprendente, porque no se había hablado antes para nada del pecado, salvo la referencia al pecado original a raíz del bautismo del cristiano (pregunta $3^{\mathrm{a}}$ ).

Resulta forzado hablar de la redención en términos de pecado, sin haber dicho antes en qué consiste el pecado, ni haber dado la más mínima información sobre el hombre que vuelve la espalda a Dios.

Vinculada con la pregunta anterior, el catecismo formula una duda en la pregunta siguiente, ya que Jesús no podía morir si era Dios. Es preciso transcribirla, porque quien redactó el catecismo, y quien lo corrigió (es lógico suponer que hubo alguna corrección), no cayeron en la cuenta del enorme error que literalmente aparece en su expresión: «P. Murió la Deidad o divinidad de N. S. Jesu Christo? R. De ninguna suerte murió su divinidad; solo su humanidad murió, porque su humanidad no es mortal ni perecedera». El empleo de términos abstractos (deidad, divinidad, humanidad) no es la mejor forma de presentar la fe, y es preferible el uso de lo concreto (Jesús como hombre, Jesús como Dios). Pero no es eso lo más grave, porque es patente que el catecismo tendría que haber enseñado en la última frase que «su divinidad no es mortal ni perecedera». Pero el error se coló en el borrador, y llegó hasta la letra impresa. Y así lo enseña el catecismo, de manera que quienes lo leyeran sin presencia de alguien que deshiciera el error saldría con el convencimiento de que Jesús era un hombre superior a los demás, que no era mortal ni perecedero. Y todavía se complica más la enseñanza cuando por un lado se enseña que Jesús murió en la cruz, y por otro se afirma en la misma pregunta que su humanidad no es mortal ni perecedera. No es fácil de asimilar ni de hacer compatible hablar de un hombre no mortal, que muere en la cruz para salvarnos.

A la altura de esta pregunta, consta anotado con tinta en el margen un «2» seguido de unos puntos suspensivos (más adelante aparecerá un 
«3»): parece que hay que entenderlo como una indicación para marcar partes en el aprendizaje, y no acometer toda la empresa de una vez, lo que denota (además de los márgenes desgastados por el uso) el empleo del texto en el aprendizaje de algunas personas que dejaron su huella en él.

\section{Sepultura y resurrección [p. 6-7]}

El catecismo no se mete en dibujos sobre la unión hipostática, y se atiene a la división clásica de alma y cuerpo, por lo que pregunta por el desplazamiento del alma de Jesús a los infiernos, asumiendo literalmente la frase del credo. Fue allá «para sacar las ánimas de los Santos Padres que estaban esperando allí su santo advenimiento».

Durante mucho tiempo se entendió esta afirmación de la fe como una presencia real, solo anímica, en el infierno (o lugar inferior) conocido con la denominación de Seno de Abraham; se apoyaba en la referencia tangencial que figura en la parábola de Jesús (Lc. 16, 19-31). Pero el catecismo adolece de un serio defecto al suponer que los destinatarios saben qué es esto, y quiénes eran los inquilinos de este habitáculo, y por qué estaban esperando la visita de Jesús. Por otro lado es preciso reconocer que ayudaban a entender esta pregunta las múltiples representaciones plásticas en que aparece Jesús a la boca del infierno recuperando una procesión de santos que le siguen, una vez traspasadas las fauces infernales.

Luego sigue la afirmación simple de que «al tercero día resucitó de entre los muertos», y que «transcurridos cuarenta días ascendió al cielo». Parece que con una afirmación como la reproducida está dicho cuando tiene que saber el cristiano. Sorprende hoy hablar con tanta simplicidad de lo que constituye un hecho fundamental de nuestra $\mathrm{fe}^{6}$; no se proponen al lector ni la manifestación del poder omnímodo de Dios sobre todas las cosas, ni la exaltación de su Hijo humillado, ni las consecuencias que esto tiene para los creyentes. El catecismo casi pasa de puntillas por el tema, que lo aborda de forma inexcusable, puesto que el credo así lo expresa. La pregunta que le sigue remite también al texto del credo, al mostrar que Jesús está sentado a la derecha del Padre.

${ }^{6}$ «Si Cristo no resucitó vuestra fe no sirve de nada; todavía seguís en vuestros pecados» $(1 \mathrm{Co} .15,17)$. 


\section{Futura venida. Escatología [p. 7-9]}

El siguiente bloque de preguntas no se detiene en la afirmación del credo sobre la promesa de retorno, pues enseña adecuadamente que vendrá para juzgar a todos, que todos resucitarán, que la finalidad de la resurrección será recibir el premio o el castigo, y que ambos serán eternos («todos los días, todas las noches, todos los años, para siempre por toda la eternidad»).

Llama poderosamente la atención el contraste entre las cinco preguntas que articulan este tema, y la única pregunta sobre la resurrección de Jesús. Es evidente que los acentos marcados por el autor del catecismo tenían un sesgo muy definido: mientras un gran tema central apenas es presentado, el interés del autor se escora hacia unos motivos en torno a la remuneración y el comportamiento cristiano que hace a la persona merecedora de salvación o de condenación.

Esto queda aún más reforzado con otras dos preguntas sobre la condición mortal de todo ser humano, y la diversa suerte de que cada uno será merecedor ante la justicia de Dios, por haber sido bueno o malo. Por tres veces seguidas el catecismo enseña esto en el conjunto de las siete preguntas sobre la escatología. El tinte moral resulta evidente.

\section{Sacramentos [p. 9-19]}

La cadencia del credo, que en cierto modo era seguido en el catecismo, queda alterada en este punto. Se desvía de manera sorprendente hacia los sacramentos. Y lo hace con una considerable extensión, mayor incluso que la que dedica a las afirmaciones presentadas hasta ahora, que se encuentran en el credo. Es cierto que tan solo hay una frase en el credo niceno que se refiera a los sacramentos al hablar de un único bautismo ${ }^{7}$.

La perspectiva en que se sitúa el autor del catecismo es marcadamente pesimista, cuando introduce el tema sacramental con estas palabras: « ¿Tiene el alma algún remedio en la Tierra para curarse después de aver quebrantado la ley de Dios por sus culpas y pecados?». La consideración de los sacramentos es la de «remedios», o, con otros términos, me-

7 «Creo que hay un solo bautismo para el perdón de los pecados». En el credo llamado «apostólico», la referencia al «perdón de los pecados» podría entenderse también como una alusión tangencial al tema de los sacramentos. 
dicinas, como los califica también algún otro catecismo contemporáneo ${ }^{8}$. El hombre es irremisiblemente pecador, y, si bien es cierto que nadie está libre de pecado, que a todos afecta, la lectura de la pregunta tal como está redactada parece dar a entender que el hombre carece de libertad y que todo lo que hace tiene que ser forzosamente malo.

El remedio a la maldad humana son los sacramentos. La perspectiva de la gracia y la amistad con Dios, su fuerza, su ayuda y sostén están ausentes de la consideración que el catecismo ofrece. Esta consideración refuerza aún más la impresión de la fecha señalada para este catecismo, pues los catecismos de esta época participaban de ella y así la presentaban.

$\mathrm{Al}$ tema de los sacramentos, el catecismo dedica nada menos que 25 preguntas, que rompen la perspectiva del credo que parecía el hilo conductor. Pero, además de valorar tan notable cifra, es obligado reconocer que se producen dos silencios, pues no se mencionan ni el bautismo ni el orden. Como tampoco dice nada de que los sacramentos son siete, es bastante fácil no caer en la cuenta de las dos omisiones. Ni siquiera se puede justificar diciendo que ha hablado del bautismo al decir en la pregunta $2^{\mathrm{a}}$ del catecismo que «soy Christiano porque estoy bautizado»; ni tampoco cabe exculpar la otra omisión afirmando que se habla del sacerdote como ministro de los sacramentos. La ausencia de estos dos sacramentos resulta evidente, sin paliativos.

Con perspectiva tridentina nítida, tras presentarlos como remedios, como está dicho, afirma que Jesús los instituyó, lo cual no era una novedad, pero había quedado reflejado en el catecismo tridentino, frente a las negaciones y silencios de los reformados, de los cuales nada sabían los indios de Guatemala.

\section{Confirmación}

El silencio sobre el bautismo aboca directamente a hablar de la confirmación, con una pregunta que extraña, al interesarse sobre por qué se

${ }^{8}$ F. BAUCELls, Fuente mystica y sagrada del paraíso de la Iglesia, Barcelona, José Altés, 1751, 400: «Qué cosa son Sacramentos? Unos remedios espirituales que nos curan y justifican»; A. MARSAL, Cathecismo explicado y predicado, Barcelona, Francisco Suriá, 1762, 276: «Fueron instituidos los Santos Sacramentos para remedio y medicina de las enfermedades de nuestra alma». 
recibe en presencia del obispo. Podría parecer una manera de realzar este sacramento, cuando en realidad se trata de que el obispo es el ministro ordinario, lo que comportaba no pocos inconvenientes a la hora de recibirlo. Sorprende aún más la respuesta que ofrece el catecismo, que en nada da a entender el aspecto de sacramento entendido como remedio, sino que marca una consideración positiva de la confirmación: «para fortalecer las Almas en la Fee Catholica y para conseguir la gracia de Dios». El término «conseguir» no es el más afortunado para explicar este sacramento. Y la respuesta ofrecida no tiene nada que ver con la presencia del obispo, asunto que se podría haber señalado en otra pregunta sobre quién lo realiza, sin mezclarlo con el efecto del sacramento.

\section{Penitencia}

Siguen seis preguntas sobre la penitencia. También aquí figura al margen en tinta un «3» como indicio de una partición en el aprendizaje; no hay otras indicaciones marginales. En la formulación de la primera pregunta sobre la penitencia, vuelve a incurrir en el mismo defecto señalado en la confirmación al fundir el motivo de ir a confesarse, con el de la presencia del ministro, el sacerdote. El efecto del sacramento es el perdón de Dios; aunque se insiste en la respuesta en la presencia del sacerdote. Pero no dice que éste actúa en nombre y por el poder de Dios, lo que hubiera sido más práctico y claro desde el punto de vista catequético. Simplemente habla de la presencia del sacerdote en la pregunta y en la respuesta.

La pregunta siguiente enseña que no hay que callar algún pecado, pues se comete una nueva culpa, y añade expresamente: «y iré a ser quemado en el Infierno». No creo que sea la manera más pedagógica de enseñar que no se debe faltar a la santidad del sacramento ni al honor debido a Dios, ya que la frase, que pudiera tratar de expresar una mayor gravedad, deja abierta la posibilidad de que se entienda mal, como si en adelante no hubiera posibilidad absoluta de perdón, y como si quien calla algo en la confesión está condenado de forma irremisible.

Como contraste con la confesión deficiente, luego sigue la exposición de las condiciones de una buena confesión: confesión entera; sin callar nada; ante el sacerdote; con dolor y arrepentimiento. Lo presenta como he señalado, aunque no con tanta claridad como para que fuera fácilmente retenido en la memoria. Recibido el perdón, señala unas normas para con- 
servar la gracia y dar pleno cumplimiento al sacramento; podrían parecer simples consejos, si bien van vinculados al sacramento mismo, en conformidad con la disciplina tridentina: hacer lo que manda el sacerdote; arrepentirse; tener propósito de rectificar; aborrecer sus culpas; y apartarse de la mala vida.

Las dos últimas preguntas sobre la penitencia son bien diversas. $\mathrm{La}$ primera de ellas señala un defecto que tienen que corregir los penitentes: no acudir al sacramento simplemente para «parlar» o para «ir a relatar mi pleito». La última pregunta precisa qué hacer ante el trance de la muerte, y la respuesta -triple- indica: Hacer una buena confesión, arrepentirse, y solicitar recibir la eucaristía. Pero no dice nada en este momento de pedir el sacramento de la unción de enfermos, del que hablará más adelante, sino que esta respuesta da pie para pasar al sacramento de la eucaristía.

\section{Eucaristía}

Comienza hablando de la presencia de Cristo en la eucaristía. Esto encadena la pregunta de dónde se lleva a cabo el sacramento, cuya respuesta es «en el Altar, por el Sacerdote quando celebra y dice la Missa». Nada hubiera ocurrido de omitir lo del altar, o haberlo situarlo en último lugar, como elemento no fundamental. La pregunta que sigue es una larga presentación de cómo se realiza esto, por las palabras del sacerdote, que convierten el pan y el vino en el Cuerpo y Sangre del Señor. De la respuesta no parece que haya que deducir que se produjera en el lector del catecismo una lectura falsa, y que pudiera malentenderse como si se tratara de palabras o fórmulas mágicas. Pero la respuesta es larga y reiterativa por duplicado, de manera que no se puede entender como una respuesta para encomendar a la memoria, sino como una explicación detallada.

A esta pregunta se vincula la siguiente en que se afirma que nada queda de pan o de vino en la eucaristía: se evita hablar de «accidentes», con una terminología filosófica ajena a muchas personas, aunque no se ahorre hablar de «substancia», con lo cual no se supera del todo la cuestión de un lenguaje abstracto y difícil; además, acorde con los términos tridentinos, aparecen expresamente los vocablos «cuerpo, sangre, alma y divinidad». 
El catecismo enseña que antes de comulgar hay que hacer una buena confesión; la afirmación, rotunda, se extiende a todos los casos, pues no figuran otros matices en el texto. En este preciso momento se introducen dos cuestiones que hubieran estado mejor situadas en lo relativo a la penitencia: ante un accidente o muerte repentina, si no hay sacerdote, qué es preciso hacer. La respuesta invita al arrepentimiento sincero, y enseña con claridad que Dios, en su misericordia, tiene en cuenta la voluntad de quien le invoca. Pero en estas dos cuestiones no se dice nada de recibir la eucaristía, lo que muestra que están fuera de contexto, y que la preocupación del autor del catecismo por dejar claro este punto tan importante le impidió colocarlas en el lugar que realmente les correspondía.

El apartado de la eucaristía se cierra con tres preguntas más: por qué se dice misa todos los días, por qué se aplica por los vivos, y por qué se aplica por los difuntos.

\section{Matrimonio}

Al tema se dedica una sola pregunta. En su formulación aparece la misma expresión que ya empleó el catecismo a raíz de la penitencia: «Por qué causa se confiessa la gente...?», que ahora es «Por qué razón se casa la gente?». La razón, única, es: para que «tengan generación en buen estado mediante este Sacramento». Las palabras «en buen estado» parece que hay que entenderlas adecuadamente en una situación moral, ante Dios, como cristianos, y social, ante los demás, aceptada y regularizada. Pero cabría entenderlas como si se refiriera a «hijos en buen estado», es decir, sanos y sin taras o defectos, lo que acentuaría aún más el carácter de remedio o medicina que se atribuye en general a los sacramentos, y por tanto también al matrimonio.

En la segunda parte del impreso, en la parte de ritual, se proponen las fórmulas para la celebración del sacramento del matrimonio, que aquí se eluden.

\section{Unción de enfermos}

Se presenta este sacramento como verdadero sacramento, por el que Dios perdona los pecados de la persona ungida; pero lo hace con una restricción, al indicar que «le perdona Dios todos los pecados veniales que 
cometió». Nada se dice de los pecados graves, que - hay que suponerloel catecismo remitiría intencionalmente a la penitencia, suponiendo que el enfermo es capaz y está en condiciones de confesarse.

Es lo único que se afirma en esta primera pregunta como efecto del sacramento, por lo que se silencia la ayuda ante el dolor o la enfermedad, y la fortaleza ante el trance de la muerte. Esto se reserva para la pregunta siguiente que presenta como efectos del sacramento el aumento de la gracia de Dios, el rechazo del demonio, y el fortalecimiento del cuerpo. Este último punto se afirma sin condiciones o reservas, de manera que parece seguirse como un efecto que produce el sacramento con seguridad absoluta.

La pregunta que sigue no suele ser nada habitual, y denota un abuso relativamente común entre los cristianos en cuya solución se empleó este catecismo: el de que recibieran o pretendieran recibir el sacramento personas sanas, no enfermas. La pregunta es oportuna para corregir este abuso; hay que recordar que a propósito de la penitencia no se señalara a la hora de una muerte previsible pedir este sacramento, cuando aquí se manifiesta con absoluta claridad que está destinado a personas enfermas que están en riesgo. Es una incongruencia haberlo silenciado en aquel momento.

La última pregunta sobre la unción de enfermos tiene un tono jurídico, pues se interesa por la bula, cuando el enfermo está para morir, ya que reporta al enfermo indulgencia plenaria y grandes gracias y perdones por concesión pontificia.

\section{Mandamientos [p. 19-20]}

Más que dar amplias explicaciones, es preferible transcribir la pregunta que viene a continuación, fuera ya del tema sacramental: «Qué es necessario para la salvación de nuestras almas? Es necessaríssima para la salvación de nuestras almas la obediencia y guarda de los diez mandamientos de Dios y de los cinco de nuestra Santa Madre Yglesia».

Es todo cuanto se dice sobre esta cuestión. Han aparecido ya otras carencias y fallos del catecismo, por lo cual he afirmado que se trata de un texto incompleto. Es obligado reiterarlo. Porque no es posible despachar toda la formación sobre la conducta del cristiano con una respuesta tan genérica que dice todo y a la vez no dice nada. Como no sea por otra fuente de información, quien solo leyera el catecismo se quedaría con la 
pregunta lógica: ¿cuáles son estos mandamientos de que el texto me habla? Pero no encontraría la respuesta en el catecismo.

Con frecuencia, y más en el siglo XVIII, hay catecismos con tratados muy extensos, interminables, sobre los mandamientos, sobre la forma de guardarlos y sobre las desviaciones y pecados que se puede cometer por no cumplirlos ${ }^{9}$. Semejante silencio en el presente catecismo obliga a pensar que se hacía de todo punto necesaria otra fuente de información además de lo que aparece escrito en sus páginas que, en esta ocasión, es nula, enteramente insuficiente.

\section{Cruz [p. 20]}

De modo brusco, el catecismo salta desde la presentación mínima de los mandamientos a hablar de la cruz. Es un tema que los catecismos han situado en distintos momentos sin que la tendencia a hacerlo al principio resulte unánime. La pregunta única habla sobre la «reverencia y adoración» de la cruz, con la respuesta conocida de la muerte de Jesús en ella.

Pero no se dice ni se enseña a hacer la cruz, a signarse y santiguarse, a las fórmulas orales habituales que acompañan este gesto identificador de los cristianos. Tampoco se dice nada de la invocación a modo de jaculatoria ${ }^{10}$, o de la celebración del Viernes santo con la evocación de la pasión y muerte en la cruz de Jesús. La brevedad del catecismo deja de nuevo un espacio vacío, que no hubiera sido demasiado complicado rellenar adecuadamente. Lo hará algo más adelante, cuando parece lógico unir esta cuestión con las que propone poco después.

9 J. A. Ramírez y Orta, Doctrina Christiana, Zaragoza, Pedro Ximénez, 1730, dedica el cuarto tomo, con 378 páginas a los cuatro primeros mandamientos, y el quinto, con otras tantas páginas, a los restantes.

${ }^{10}$ La expresión de JUAN DE ÁviLA es: «Adorámoste, señor Jesu Christo, y bendezímoste, que por tu santa Cruz redemiste al mundo» (ver L. RESINES, JUAN DE ÁVILA, Doctrina cristiana que se canta, Madrid, Khaf, 2012, 254). La expresión de ANDrÉs FLórez cambia ligeramente: «Adórote, señor mío Jesucristo, que por tu santa cruz redimiste el mundo» (A. FlóREZ, La doctrina cristiana del ermitaño y del niño, Alcalá de Henares, Juan de Brócar, 1546, 64v [ver C. CRÉmedes La «Doctrina cristiana» de Fray Andrés Flórez (1546), Valencia Edicep, 2000, 139]). 


\section{Imágenes [p. 20-21]}

Se supone que al hablar de la cruz estaría presente en la memoria de los lectores, o bien a la vista, una cruz con la imagen del Crucificado. De ahí se pasa a hablar de las imágenes (pinturas, tallas) de los santos. La pregunta única sobre este tema tiene una formulación ambigua, con un elemento claramente positivo tal como consta en la pregunta y en la respuesta, y con otro claramente negativo conforme a la misma expresión.

El elemento positivo es que pregunta y respuesta afirman que las imágenes no son dioses. El riesgo de conversiones con escaso convencimiento latía siempre; la supervivencia de la ancestral idolatría estaba a la orden del día. La afirmación que el catecismo hace de modo firme sobre el monoteísmo podría no ser suficiente, y los santos -las imágenes de los santos-, podían ser tomados por nuevos dioses que sustituyeran al antiguo panteón. No es tan imaginario el riesgo, pues no son pocas las personas que toman las imágenes como verdaderos amuletos o fetiches (cuando no dioses), ante los cuales hay que rezar, ofrecer velas u otros dones. Por lo tanto es muy valiosa la enseñanza del catecismo de no tomarlos por dioses, sino como amigos de Dios que enseñan y animan con su vida a cumplir su voluntad divina.

En cambio, la parte negativa se vincula con la expresión utilizada en el texto, que dice: «Por qué adoras y reverencias las imágenes de los Santos...?». Es negativo por partida doble: por el empleo del vocablo «adoras»; y porque la misma expresión se utiliza en la pregunta anterior para hablar de la cruz («Por qué reverencias y adoras a la Santa Cruz?»). El mismo hecho de emplear la palabra «adorar» con ligereza está en contradicción con la enseñanza bíblica que repite una y otra vez la exclusividad de este tratamiento reservado solo a Dios. No es infrecuente encontrar en autores de catecismos este empleo poco exigente que pone en cuestión la honda actitud de adoración del creyente hacia Dios considerado como el único que merece dicho trato ${ }^{11}$. El otro motivo que pone una apreciación

11 A. De Orozco, Cathecismo provechoso, Zaragoza, Juan Millán, 1568, c. VIII: «Todos los espíritus celestiales se admiran viéndose siervos de su Creador y viendo una mujer más santa y gloriosa que todos ellos, la cual es madre verdadera de Dios, adóranla y acátanla como a Señora y Reina, y alaban al Señor que tanto la engrandeció». Más adelante reitera la misma expresión (L. Resines, Catecismo provechoso, en R. LAZCANo (ed.), Alonso DE OROZCO. Obras completas, I, Obras castellanas (I), Madrid, BAC, 2001, 714. 
dudosa en la cuestión de las imágenes de los santos es el uso de la misma expresión para éstas y para la cruz; esto da a entender que para el autor del catecismo merecen idéntica apreciación, y que el término «adorar» queda devaluado precisamente por su empleo indistinto para las imágenes y para la cruz. En otro lugar del catecismo [p. 4] había enseñado con precisión que la virgen María no es diosa; ahora repite que las imágenes de los santos, y los santos mismos no son dioses. Pero el empleo del término «adorar» enfanga el asunto en lugar de dejarlo radiante.

\section{La Iglesia [p. 21]}

Había hablado con anterioridad de la Iglesia al mencionar sus mandamientos junto a los de Dios; y también al mencionar los sacramentos de la Iglesia. Pero en este momento dedica dos cuestiones a la Iglesia, aunque lo hace francamente mal, pues empieza por plantear la posibilidad de error en la Iglesia, para pasar después a dar una definición de ella. Lo lógico hubiera sido lo contrario.

Sobre la posibilidad de que la Iglesia cometa errores, la respuesta resulta perfecta, pues no está abonada por la capacidad o ciencia de quienes forman parte de la Iglesia, sino por la asistencia del Espíritu Santo que la gobierna. No hay nada que objetar. Con todo, hubiera sido mejor incluir la advertencia de que esta inerrancia se ciñe al campo propio de la religión, mientras que la afirmación universal parece extender las afirmaciones seguras de la Iglesia en todos los terrenos, lo cual no es cierto.

En cuanto a la definición que ofrece de Iglesia, señala tres aspectos: la congregación de los cristianos; la aceptación de Jesús; y la obediencia al Papa. Se refiere, naturalmente, a la Iglesia católica. Es una definición típica de los términos jurídicos, que excluye a cuantos no están visiblemente bajo su reconocimiento. No se hace referencia alguna a otros grupos cristianos (posiblemente desconocidos para los destinatarios directos del catecismo), ni tampoco alude a los paganos que no habían aceptado la predicación del evangelio, o simplemente que ni siquiera la conocían. Posiblemente el catecismo refleja para la época del siglo XVIII una amplia aceptación social en el ambiente de Guatemala al que está destinado, y en el que apenas surge el paganismo de manera abierta, pero que puede estar latente en cristianos de escaso convencimiento. 


\section{Comunión de los santos [p. 21-22]}

Llegados a este punto del recorrido del catecismo, cabe preguntarse si el verdadero hilo conductor es el credo, o si, al contrario, hilvana unas cuestiones a continuación de otras, sin demasiado orden. En caso de admitir que el credo organiza las preguntas, las desviaciones tan notables que ya han aparecido hacen muy difícil mantener en pie tal afirmación. Por eso mismo, sorprende ahora que dedique una cuestión al tema de la comunión de los santos «que se dice y enseña en el credo».

Nada hubiera llamado la atención si estas palabras no hubieran aparecido, y figuraran como un asunto más. Acaso buscaba una apoyatura en la profesión de fe. La respuesta que ofrece a este tema señala que la comunión de los santos se justifica puesto que todos los miembros de la Iglesia somos hijos del mismo Padre. Es una respuesta simple, que no entra en la cuestión de la vinculación con los cristianos ya fallecidos y salvados; y tampoco aborda que los cristianos no católicos son igualmente hijos del mismo Padre, del mismo Dios, por la recepción del mismo bautismo.

\section{De nuevo la cruz [p. 22-23]}

Ha aparecido ya que la veneración y respeto a la cruz responde al aprecio por la muerte salvadora de Jesús; pero a continuación vincula esta única pregunta sobre la cruz con la cuestión de las imágenes de los santos. He indicado que nada dice entonces de las formas de realizar la cruz.

Pero retoma el asunto en las cuatro preguntas que aparecen a continuación. Es una muestra más del desorden con que el texto presenta una y otra materia, que denota una falta de organización debidamente estructurada.

En la primera de estas cuatro cuestiones recomienda el empleo de la cruz como solía ser habitual: al comienzo de alguna obra, ante algún peligro o alguna tentación. Las otras tres preguntas siguen el orden establecido de hacer la cruz en la frente, boca y pecho, y en cada una de las tres ocasiones señala las palabras que han de pronunciarse, con una fórmula que no resulta enteramente usual, acaso por acomodación al cachiquel, aunque no es probable, pues podría adecuarse con facilidad a la expresión más común entre cristianos. La que el catecismo ofrece es: «Por la señal de la Santa Cruz | líbranos Señor Dios nuestro | de las manos de nuestros enemigos». Queda constancia de ello. 


\section{Suerte de los cristianos [p. 23-24]}

Cuando planteó el tema de la escatología, enseñó que los hombres recibirían premio o castigo del Dios justo, acorde con sus obras. Ahora reitera el tema, pero con un matiz peculiar, pues se refiere explícitamente a los cristianos. Es el final del Catecismo. Parece que hay que entender que quien ha leído y aprendido lo anterior es cristiano, y cristiano bien formado.

El hecho de preguntar si se salva el cristiano que no obedece ni guarda la ley de Dios (o a la inversa, cuál es la suerte del que guarda su ley) lleva a pensar que solo el hecho de ser cristiano no garantiza de forma automática la salvación. Supone que la pertenencia externa a una comunidad o grupo social de bautizados no exime del cumplimiento personal de las obligaciones que dimanan de su condición de cristiano. No se puede entender de otra forma la reiteración de este asunto, que ya había sido abordado [p. 8-9], sin mención expresa de la condición de cristianos ${ }^{12}$.

En este punto termina el catecismo. Como hablaba en la última pregunta de disfrutar del cielo, la conclusión en castellano es «Así sea», que en cachiquel se expresa como «Quere ok tux». Tipográficamente, las dos columnas del texto castellano y cachiquel son clausuradas con una abundante serie de estrellas dispuestas en forma decreciente de colofón en cada una de ellas.

\section{Parte Segunda: Ritual}

Concluido el catecismo en la p. 24, las restantes [p. 25 a 32] están destinadas a un ritual sacramental que tiene tres partes netas:

- modo de dar el viático

${ }^{12}$ La reiterada proposición de la salvación se sitúa en la misma línea de la preocupación que refleja J. DE CAMINO, La religión o instrucciones sobre los misterios de la fe y reglas más esenciales de la moral christiana, Madrid, Antonio de Sancha, 1786, 293: «... el número de los réprobos es asombroso y corto el número de los escogidos... es cierto que serán muchos los que consigan la salud eterna... siempre irán al cielo los niños baptizados, hijos de los Catholicos y de los Herejes, que comprenderán un número tan prodigioso que de las cuatro partes de los escogidos, puede decirse que estos niños baptizados harán más de las tres». 
- preguntas a los que se casan

- Alabado.

\section{Modo de dar el viático en lengua cakchikel [p. 25-31]}

Constituye el ritual para esta situación concreta, pues ni siquiera abarca la recepción del sacramento de la unción de enfermos, como se verá y como así consta establecido en el ritual romano. Se entreveran los idiomas castellano, latino y cachiquel. El castellano, a modo de rúbricas, para que el sacerdote observe las prescripciones; el latín en las fórmulas de oración prescritas por el ritual romano, que así las empleaba; el cachiquel en las ocasiones en que se dirige al enfermo que va a recibirlo.

Comienza con una parte de rúbrica que supone el saludo (Pax huic domui), con su respuesta latina. Deposita el santísimo en una mesa, y asperja al enfermo con la fórmula latina establecida (Adjutorium nostrum, Domine exaudi, Dominus vobiscum). Sigue íntegramente en latín la oración Exaudi nos, Domine Sancte, establecida para la ocasión.

Luego se dirige al enfermo con una exhortación en cachiquel, en que se incluye -deduzco- una pregunta sobre si desea recibir el sacramento de la eucaristía que ha llevado hasta su vivienda. El ritual romano indica que el sacerdote compruebe si el enfermo está dispuesto para recibir el sacramento o si desea confesarse antes de comulgar, lo cual se contiene aquí en forma breve en cachiquel. Para ello, señala que se diga la confesión general por el propio enfermo o por alguno en su nombre, a la que siguen las fórmulas latinas Confiteor Deo..., misereatur... indulgentiam...

Después señala que el sacerdote hace al enfermo una serie de preguntas teniendo la cruz en la mano. Las preguntas que siguen (diez en total) están en cachiquel, y llevan adjunta la respuesta que ha de dar el enfermo; es una especie de diálogo previsto o ritualizado, pues no son preguntas que dejen espontánea la respuesta del enfermo. Deduzco que se trata de invitaciones para pedir perdón de los pecados cometidos, y a recordarlos en grandes líneas. Terminadas las preguntas, el texto indica que el sacerdote dé a besar la cruz al enfermo (Estas diez preguntas y el beso a la cruz no forman parte del ritual romano).

Tomando el Santísimo en sus manos, el sacerdote diga Ecce Agnus Dei, ecce qui tollit peccata mundi (consta en latín); tras esto, aparecen 
otras cinco preguntas en cachiquel, dirigidas al enfermo con su respuesta ya prevista. Hay que suponer que son una invitación a recordar la presencia de Cristo en la eucaristía, y un apremio a recibirlo. Luego está indicado que diga tres veces con el enfermo una invocación, que podría ser: Señor, no soy digno... (está en cachiquel), pero la triple repetición podría indicar que se trata de la invocación: Cordero de Dios que quitas el pecado..., expresada antes en latín, y ahora dicha en cachiquel.

Tras haberle dado la comunión, sigue, también en cachiquel, una invocación con su respuesta tipificada. Esta invocación u oración es diferente de la del ritual romano, pues alude en cachiquel a la Iglesia, cosa que el ritual no incluye.

Termina con una indicación que señala que, volviendo a la iglesia, el sacerdote anuncie las indulgencias concedidas. Tales indulgencias eran aplicables a quienes acompañaran al viático en comitiva. Tal anuncio (que también aparece en el ritual romano) consta aquí en cachiquel y hace referencia al papa Gregorio: remite a Gregorio XIII, quien había concedido tales indulgencias a los Cofrades del Santísimo Sacramento y a los acompañantes del viático.

\section{Preguntas que se han de hacer para los que se casan [p. 31-32]}

La rúbrica o indicación en castellano muestra con evidencia el interrogatorio a los contrayentes a la hora de la celebración del matrimonio. La indicación o rúbrica, señala las tres preguntas que se hacen primero a la mujer y las otras tres que se dirigen después al hombre.

En este momento el ritual cachiquel abandona el ritual romano y sigue el ritual toledano, de uso en España y América, pues recoge las tres preguntas sobre la aceptación del cónyuge, la entrega como esposo o esposa y la aceptación del otro. El ritual toledano figura como apéndice del ritual romano; este solo formula una pregunta a cada esposo.

Aunque las preguntas están en cachiquel, cuando se pregunta a la mujer hay un paréntesis en castellano que introduce una variante particular al indicar «(si fuere viudo)» el hombre con quien va a contraer matrimonio: otro tanto sucede cuando se pregunta al varón, pues entonces la adaptación señalada es para el caso de que ella fuera viuda. 
Como culminación del diálogo, la rúbrica indica (en castellano) la expresión que ha de utilizarse para la entrega de las arras, en cachiquel; y se añade también en castellano la respuesta de la esposa: «responde ella», a lo que siguen en cachiquel las palabras de aceptación de las arras como signo del matrimonio contraído. El ritual toledano pone este breve diálogo: «Esposa, estas arras te doy en señal de matrimonio»; «Yo las recibo» ${ }^{13}$.

\section{Alabado [p. 32]}

En la tercera y última parte de este breve ritual solo el título aparece en castellano como está transcrito: «Alabado». El resto está en cachiquel, pero aparecen las expresiones que se refieren al Santíssimo Sacramento, a Jesucristo y a Santa María, que llevan a pensar en la misma oración conocida, con la variante de haber sido traducida. Termina con la expresión «Quere tak tux», casi igual que la que figuraba en el catecismo al final de la columna del texto cachiquel (allí era «Quere ok tux» [p. 24]).

\section{VALORACIÓN}

La del catecismo, comentado con más detalle, al poder seguir el texto en castellano está casi elaborada, al señalar los aciertos y deficiencias del texto. Todo ello, en la suposición de que el texto cachiquel y el castellano coincidan, puede aplicarse a los dos.

El catecismo está francamente desordenado, sin un criterio que siga un orden, y lo que parece que podría atribuirse al credo se ve desbancado por la continuidad irregular de unas y otras preguntas, de unos y otros temas.

Además, como he indicado, resulta gravemente incompleto. La condición de texto breve no exime de presentar cuestiones de mayor importancia; exige evitar repeticiones innecesarias; reclama que las preguntas

13 Rituale Romanum Pauli V, Pont. Max. Iussu editum et a Benedicto XVI auctum et castigatum cui amplissima accedit benedictionum et instructionum appendix, Romae, Ex Typographia Polyglotta, 1858, 81-85. Lo relativo al ritual del viático, así como de que corresponde al ritual toledano se encuentran en un ejemplar de Ritual, que carece de portada, pero que pudiera datar del siglo XVIII: viático (p. 83-89); proclamación de las indulgencias (p. 447); matrimonio (p. 457-458, en latín; y 458-459 en castellano). 
en torno a un mismo tema se contemplen seguidas. Pero es incompleto porque no hay más que una alusión tangencial a los mandamientos. Y también porque no hay una sola ocasión en que se haga presente la oración. Puede discutirse si falta o sobra una pregunta concreta, pero no es posible decir que se ofrece la fe cristiana, sin decir algo más sobre los mandamientos, y sin hacer referencia a la oración.

Es muy posible que estas cuestiones fueran abordadas por los misioneros en otro momento o de otra forma, pues que no resulta fácil olvidarlas. Pero no consta en el texto, que es lo que en esta ocasión se trata de examinar.

Como texto de catecismo he dejado constancia de sus aciertos y fallos. Lo que no es posible sopesar es la labor del catequista, las explicaciones, la actuación diaria, las respuestas que pudiera dar a las preguntas vivas no previstas en estas páginas. El catecismo no es nada sin la presencia, la viveza y el testimonio del catequista.

El ritual no miente en su título primero sobre la forma de llevar el viático; ni engaña acerca de la celebración matrimonial en el diálogo y aceptación esenciales.

Es claro que no es un ritual romano completo, que contemplara la realización de otros sacramentos u otras celebraciones. Se ciñe con brevedad a lo que propone, y se percibe la extraña mezcla de idiomas, que era lo que en aquel momento era usual en la celebración. Así hay que admitirlo.

Con estos límites, y con estos recursos los misioneros franciscanos y dominicos (y quizá también los mercedarios que llegaron más tarde, más el clero nativo) llevaron a cabo en Guatemala la parte de catequesis que aquí nos es dado conocer. Y con ello contribuyeron al sostenimiento de la fe cristiana en aquellas tierras.

\section{Cotejo con la Doctrina Christiana de Marroquín}

El presente catecismo, situado en el siglo XVIII, y rigurosamente de autor anónimo, no ofrece duda que fue empleado en Guatemala. Por eso mismo resulta imprescindible echar una ojeada a la Doctrina Christiana que publicó Francisco Marroquín en 1556, con la colaboración de los dos religiosos franciscano y dominico ya indicados. 
Al hacerlo, no hay punto posible de comparación entre uno y otro catecismos, pues aunque los dos contribuyeran a dar a conocer la fe, sus respectivos textos no tienen nada entre sí. No vale la pena repetir lo ya dicho sobre este catecismo, sino que, con ello presente, la diferencia salta a la visa.

La Doctrina que publicó Marroquín entra de lleno en la categoría de las cartillas de la doctrina cristiana, que presentan los formularios habituales, pero carentes de toda explicación ${ }^{14}$. Se trataba con ello de que los bautizados aprendieran las oraciones y formularios más importantes y los hicieran suyos, de memoria, aunque las explicaciones -si las había- vinieran por otra vía.

El contenido de la Doctrina impresa por Marroquín es el siguiente:

Señal de la cruz

Padrenuestro

Avemaría

Credo

Salve

Artículos de la fe

Mandamientos de Dios

Mandamientos de la Iglesia

Sacramentos

Declaración del pecado venial

Declaración del pecado mortal

Por cuatro cosas se perdona el pecado mortal

Los siete pecados mortales [capitales]

Las siete virtudes contra los vicios

Los enemigos de nuestra alma

Las obras de misericordia

La confesión [yo pecador]

Cómo ha de oír misa el cristiano y lo que ha de hacer cuando entrare en la iglesia

La bendición de lo que se come

${ }^{14}$ L. Resines, Catecismos americanos del siglo XVI, Valladolid, Junta de Castilla y León, 1992,21-22, con la diferenciación entre cartillas, cartillas de la doctrina cristiana y catecismos. 
Después de comer, hazimiento de gracias

Protestación de la fe

Acto de contrición

Alabado.

Los tres últimos formularios constan exclusivamente en cachiquel, mientras todos los demás figura en cachiquel y castellano a dos columnas. El único que se repite en los dos catecismos es el último, «Alabado», que en ambos casos consta en cachiquel; pero los textos de ambas oraciones, comparados, no coinciden en absoluto.

Por tanto no hay más remedio que señalar que el más antiguo, el de Marroquín, constituye una cartilla de la doctrina, para ser aprendida y repetida, mientras que el segundo, el del siglo XVIII contiene explicaciones de las que el otro carece. Podría decirse que uno construye sobre los cimientos del otro. La ausencia de toda referencia a la oración, detectada en el catecismo posterior, puede ser suplida si se tiene a mano un ejemplar del catecismo primero. Pero ni una sola alusión mínima permite hacer referencia a lo de la primera cartilla, y en lo impreso en el catecismo del XVIII se presenta sin más como texto plenamente autónomo.

\section{El Confessionario, ¿UN COMPlemento?}

Todo cuanto sigue tiene un valor secundario respecto al catecismo examinado, porque el Confessionario del que hablaré a continuación no tiene nada que ver, en principio, con este catecismo examinado.

Se trata de otro impreso distinto, un folleto de seis hojas (12 páginas). Tiene un desgarro en la hoja primera (que hace perder un poco del texto), y en una cubierta de papel que lo protege. Aparentemente está impreso en la misma imprenta en que se hizo el Catecismo, pues emplea el mismo tipo de letra.

Como el impreso anterior, éste carece igualmente de nombre de autor, de señas de imprenta (pie, colofón, fecha), o de cualquier otro signo de identificación. Su título, a plana completa, dice así Confessionario en lengua goatimalteca, y una anotación a lápiz de tinta, sin duda posterior, junto a él precisa «Cachiquel». El mismo patrón de anotación, realizado por la misma mano señala el pie de la página con el mismo lápiz de tinta: «Del tiempo de la Conquista. Estaba entre los libros de los PP. Capuchi- 
nos de la Antigua. Carlos Sánchez». Este anotador que da su nombre ofrece al lector un marco confuso. La primera anotación que se refiere al «tiempo de la Conquista» no permite concretar mucho más. La impresión de un impreso del siglo XVIII salta por encima de dos siglos de presencia española, sin saber desde cuándo ha sido usado ni tampoco si es reproducción de otro anterior. También permite saber que procede de la ciudad de La Antigua, en Guatemala; pero aporta la información de que pertenecía a papeles de los capuchinos, diversos de los franciscanos. Por otro lado nada se puede decir sobre autor alguno ni pertenencia a orden religiosa, pues poseer un impreso no equivale a decir que sea suya la autoría.

El texto del impreso consta a dos columnas: la de la izquierda en castellano, con letra cursiva; la de la derecha en cachiquel con letra redonda. Las páginas 11 y 12 tienen el texto a plana completa.

Una breve introducción al sacramento de la penitencia aconseja al penitente lo que debe hacer al acudir al sacramento y cómo ha de haber pensado antes en sus pecados. Tras ella, unos titulillos interrumpen las columnas para señalar progresivamente a qué mandamiento se refieren las preguntas que siguen: «Primer mandamiento...», etc. En cada mandamiento el número de preguntas es desigual, acomodado a la materia objeto del mandamiento:

$1^{\mathrm{o}}$ mandamiento - 4 preguntas

$2^{\circ}$ mandamiento - 5 preguntas

$3^{\circ}$ mandamiento -7 preguntas

$4^{\mathrm{o}}$ mandamiento - 5 preguntas

$5^{\circ}$ mandamiento - 5 preguntas $6^{\circ}$ mandamiento - 25 preguntas

$7^{\circ}$ mandamiento - 7 preguntas

$8^{\circ}$ mandamiento - 7 preguntas

$9^{\circ}$ mandamiento - 1 preguntas

$10^{\circ}$ mandamiento - 4 preguntas

Es evidente la preocupación moral por el sexto mandamiento que supera con creces a todos los demás, para indagar sobre las posibles faltas cometidas contra la castidad, o contra la fidelidad matrimonial, en las que se centra con preferencia.

Son preguntas que formula el sacerdote, que quedan abiertas, sin una respuesta tipificada, para que el penitente conteste adecuadamente según su situación. Creo que vale la pena destacar en el primer mandamiento una serie de preguntas sobre la brujería y la idolatría, que son buena muestra de la pervivencia larvada en el interior de las conciencias. En el se- 
gundo mandamiento, frente al no jurar, hay unas preguntas sobre el deseo de que un rayo matara a algún prójimo (cabría presentarlas mejor en el quinto mandamiento). Sobre el tercer mandamiento las preguntas se centran en la misa dominical y en los ayunos establecidos. Las preguntas sobre el cuarto mandamiento se centran en la falta de respeto hacia los padres, o el deseo de su muerte. Las del quinto mandamiento interrogan sobre el hecho o el deseo de dar muerte a alguien, el mal trato de palabra, o el conato de suicidio (comer «tierra o tizate» ${ }^{15}$ ).

Las preguntas numerosas sobre el sexto mandamiento, como está indicado, interrogan sobre las posibles transgresiones morales hacia uno mismo, hacia los demás, y hacia la fidelidad matrimonial. Sobre el séptimo mandamiento las indagaciones son sobre el robo o la apropiación indebida, particularmente los bienes de los menores (se hace referencia al cacao o a los cacahuetes, como productos de la tierra). En torno al octavo mandamiento las cuestiones se centran sobre la mentira y el falso testimonio, pero incluye cuatro preguntas sobre los juramentos, que hubieran estado mejor situadas entra las del mandamiento segundo. La única pregunta sobre el noveno mandamiento interroga sobre el deseo de pecar con una mujer casada. Y, finalmente, las del décimo mandamiento giran sobre el deseo de los bienes ajenos, aunque no aparezca la palabra envidia. La última pregunta, situada en este contexto, inquiere si el penitente tiene algún pecado más que confesar.

Terminado el interrogatorio hay, a plana completa una exhortación al verdadero arrepentimiento, primero en castellano y luego en cachiquel. El texto termina con una serie de siete preguntas sobre la situación personal de quien se confiesa, que podrían estar perfectamente situadas junto con las que abren el confesionario.

15 Desconozco a qué producto nocivo (vegetal, animal o mineral) se refiere. Parece que ingerir productos no alimenticios no era privativo de los indios americanos, pues también encontramos testimonios en España: Pedro DE LePE, Catecismo cathólico, Madrid, 1699, 230; FrAnCISCO LeAl Gómez DE LeÓn, Colección de pláticas doctrinales y morales, Madrid, 1816, 216: «- ¿Has comido cosas nocivas a la salud en cantidad notable, v. gr., tierra, cal, pizarra, sal, etc?». Estos dos testimonios citados añaden, entre otros ingredientes del "menú", carbón, vinagre, barro o sal en grano. No se han ocupado de proporcionarnos las recetas. Semejante práctica llega incluso a ser constatada, por sorprendente que parezca, en el siglo XX: Padres de la Compañía de Jesús, Tesoro del pueblo, o sea, Catecismo de la doctrina cristiana, y Libro de la Santa Misión, Salamanca, 1926, 75. 
El hecho de que el Catecismo estudiado no incluya explicaciones sobre los mandamientos, podría encontrar una justificación en el uso complementario del Confessionario, en el caso de que ambos impresos estuvieran juntos en un solo folleto. Como no es así, se difumina el valor de complemento, y hay que entenderlos como cosas distintas que pudiera ser que en ciertos momentos concurrieran en la misma persona. Pero no siempre tuvo que ser así. Por lo tanto, subsiste la nota negativa del Catecismo de omitir la formación moral en torno a los mandamientos; ésta no se identifica plenamente con la preparación para una confesión, que es lo que proporciona este otro folleto.

\section{Biblografía}

F. BAUCELls, Fuente mystica y sagrada del paraíso de la Iglesia, Barcelona, José Altés, 1751.

J. DE CAMINO, La religión o instrucciones sobre los misterios de la fe y reglas más esenciales de la moral christiana, Madrid, Antonio de Sancha, 1786.

CONFESSIONARIO en lengua goatimalteca.

C. CRÉmedes La «Doctrina cristiana» de Fray Andrés Flórez (1546), Valencia Edicep, 2000.

A. Flórez, La doctrina cristiana del ermitaño y del niño, Alcalá de Henares, Juan de Brócar, 1546.

A. Gómez CARrillo, Estudio histórico sobre la América Central, San Salvador, 1884 .

Francisco Leal Gómez de LeÓn, Colección de pláticas doctrinales y morales, Madrid, 1816.

Pedro de LePe, Catecismo cathólico, Madrid, 1699.

A. Marsal, Cathecismo explicado y predicado, Barcelona, Francisco Suriá, 1762.

F. Marroquín, Catecismo y Doctrina Cristiana en idioma Utlalteco, por el Illmo. Sr. D. Francisco Marroquín, Obispo de Guatemala, México, Juan Pablos, 1556.

J. T. Medina (ed.), Doctrina cristiana en lengua guatemalteca, ordenada por el Reverendísimo Señor Don Francisco Marroquín, primer obispo 
de Guatemala, y del consejo de su Majestad, con parecer de los intérpretes de las religiones del Señor Sancto Domingo y San Francisco Fray Juan de Torres y Fray Pedro de Betanzos, Santiago de Chile, Imp. Elzeviriana, 1905.

José Milla, Historia de la América Central (Guatemala), t. I, 1859; t. II, 1882.

A. De Orozco, Cathecismo provechoso, Zaragoza, Juan Millán, 1568.

PAdRes de la Compañía de Jesús, Tesoro del pueblo, o sea, Catecismo de la doctrina cristiana, y Libro de la Santa Misión, Salamanca, 1926.

J. A. Ramírez y Orta, Doctrina Christiana, Zaragoza, Pedro Ximénez, 1730.

RELACIÓN del espantable terremoto que agora nueuamente ha acontecido en las indias en vna ciudad llamada Guatimala; es cosa de grande admiración y de grande exemplo para que todos nos enmendemos de nuestros peccados y estemos apercibidos para quando Dios fuere seruido de nos llamar.

L. Resines, Catecismo breve de Fray Pedro Vives (Edición crítica), Valencia, Ayuntamiento de Valencia, 2002.

L. Resines, Catecismo provechoso, en R. Lazcano (ed.), Alonso de OrozCO. Obras completas, I, Obras castellanas (I), Madrid, BAC, 2001.

L. RESINES, Catecismos americanos del siglo XVI, Valladolid, Junta de Castilla y León, 1992.

L. Resines, JUAN DE ÁVILA, Doctrina cristiana que se canta, Madrid, Khaf, 2012.

Rituale Romanum Pauli V, Pont. Max. iussu editum et a Benedicto XVI auctum et castigatum cui amplissima accedit benedictionum et instructionum appendix, Romae, Ex Tipographia Polyglotta, 1858.

VAE ri qutubal qhabal, salakiçabal pe richim Christianoil tzik Doctrina Christiana tucheex. 